\title{
Strobilanthes twangensis (Acanthaceae), a new species from the East Himalayas
}

\author{
John R. I. Wood ${ }^{1,2}$ (D), Dipankar Borah ${ }^{3}$, Lod Yama ${ }^{4}$ \& Puranjoy Mipun ${ }^{5}$
}

Summary. A new species, Strobilanthes twangensis J.R.I.Wood \& D.Borah is described from Arunachal Pradesh State in northeastern India near the border with Bhutan and Tibet. The new species is illustrated with photographs and its possible relationships with other Himalayan species are discussed.

Key Words. Arunachal Pradesh, endemic, India, Tawang.

\section{Introduction}

Species of Strobilanthes Blume have long been known from along the southern slopes of the Himalayas from Afghanistan in the west to Myanmar and China in the east. In general, species diversity rises eastwards and there are many local endemic species in Nepal, Bhutan and Arunachal Pradesh. All three regions have been largely inaccessible for botanical exploration for extensive periods over the last two hundred years and their botanical riches have only gradually been revealed. Arunachal Pradesh remains probably the least known of the three regions with only occasional visits by botanical explorers like William Griffith and Frank Kingdon Ward in colonial times, and few in the immediate post-colonial era. Only in recent years has access become easier resulting in the rediscovery of many poorly known species in the last decade (Wood 2016).

Although a tentative list of 22 species of Strobilanthes occurring in Arunachal Pradesh was provided by Wood (1994), no updated list has subsequently been published. According to our reckoning, 32 species are currently known from the state including the new species described below. Several additional species are likely to occur given their presence in neighbouring parts of Tibet or Bhutan including $S$. medogensis (H.W.Li) J.R.I.Wood \& Y.F.Deng, S. urophylla Nees, S. extensa (Nees) Nees and S. cruciata (Bremek.) Terao. Certainly, two very rare species previously known from elsewhere in India, S. pterygorrhachis C.B.Clarke and S. glabrata Nees have been found recently in the state. Six species are probably endemic to the state: S. oxycalycina J.R.I.Wood, S. parvifolia J.R.I.Wood,
S. rhombifolia C.B.Clarke, S. secunda T.Anderson, S. tubiflos (C.B.Clarke) J.R.I.Wood and the new species described below.

Three of us (Dipankar Borah, Lod Yama \& Puranjoy Mipun) have had the good fortune to visit the Tawang District in the extreme northwest of Arunachal Pradesh State. This is inhabited by the Monpa people and is the smallest district in the state lying adjacent to Bhutan in the west and Tibet (Xixang) to the north. The district encompasses a wide range of vegetation types from mixed temperate forest at around $2000 \mathrm{~m}$ to alpine vegetation at around $4500 \mathrm{~m}$. Temperate forest is an ideal habitat for Strobilanthes and the discovery of a new species in this zone, in and around the Jang township, is not entirely unexpected. The following description is based on field observations, examination of the dried type specimen and photographs of important morphological features of fresh specimens (Fig. 1).

Strobilanthes twangensis J.R.I.Wood $\mathcal{E}$ D.Borah, sp. nov. Type: India, Arunachal Pradesh, Tawang Distr., Jang, 27³4'631"N 9159'025"E, 2524 m, 1 Sept. 2018, Dipankar Borah, Lod Yama E Mipun Puranjoy 098 (holotype CAL, isotypes ARUN, ASSAM).

http://www.ipni.org/urn:lsid:ipni.org:names:77197997-1

Weakly anisophyllous perennial herb; stems decumbent, rooting at nodes, forming extensive colonies on forest banks (Fig. 2), eventually ascending to c. $50 \mathrm{~cm}$ high, glabrous. Leaves petiolate, slightly

\footnotetext{
Accepted for publication 25 June 2019. Published online 9 September 2019

1 Department of Plant Sciences, University of Oxford, South Parks Road, Oxford, OX1 3RB, UK.

2 Honorary Research Associate, Royal Botanic Gardens Kew, Richmond, Surrey, TW9 3AE, UK. e-mail: jriwood@hotmail.com

3 Department of Botany, Rajiv Gandhi University, Rono Hills, Doimukh, 791112, India.

${ }^{4}$ Centre for Bioresources and Sustainable Development, Department of Biotechnology (Centre of Excellence), Pimin, Papum Pare District, Arunachal Pradesh, 787031, India.

${ }^{5}$ Centre for Advanced Studies in Botany, North Eastern Hill University, Shillong, 793022, India.
} 

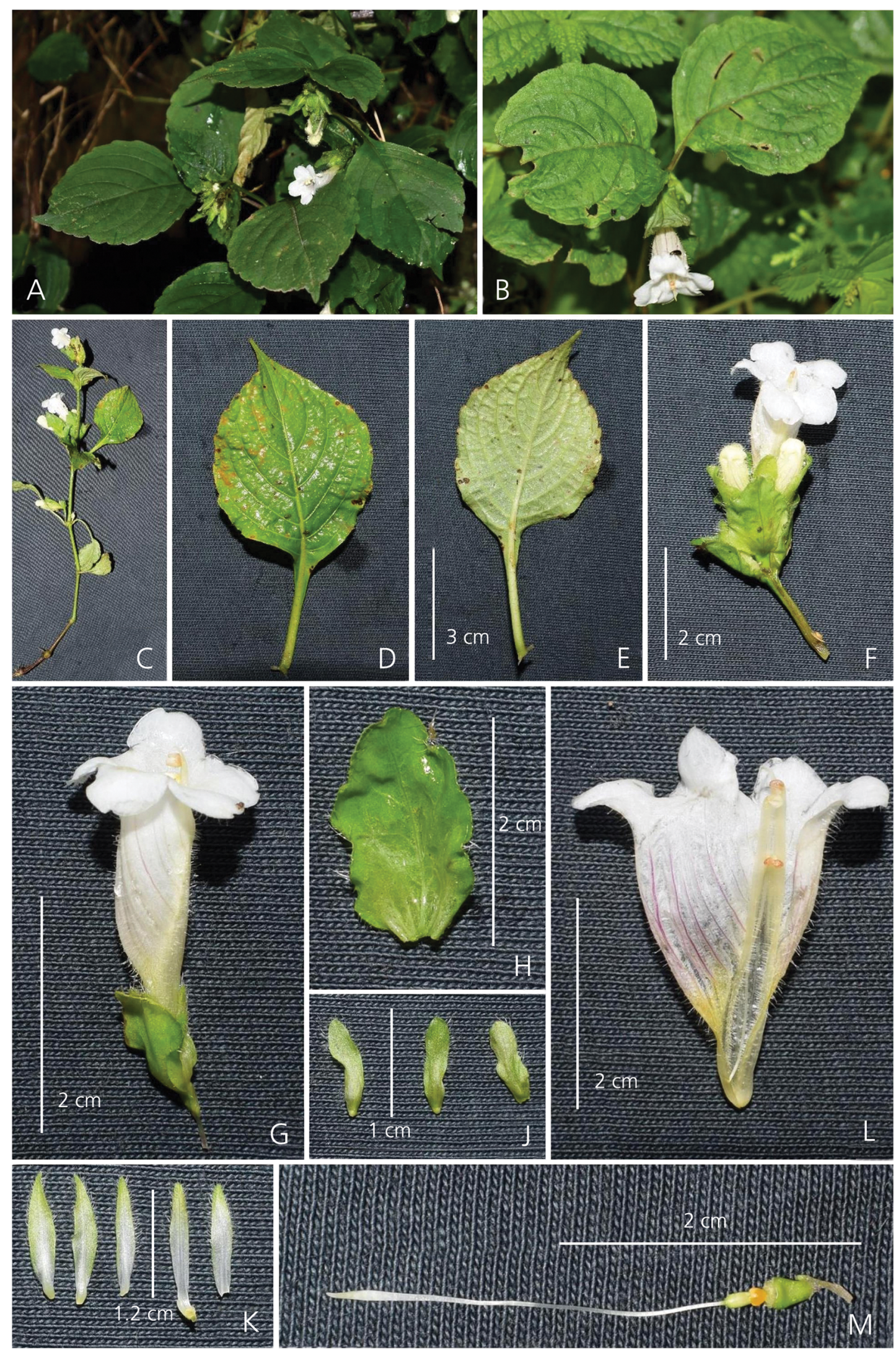

Fig. 1. A habit; B inflorescence from above; C stem showing leaves and inflorescences D leaf (adaxial surface); E leaf (abaxial surface); F inflorescence; G corolla with bract; $\mathrm{H}$ bract; J bracteoles; K calyx lobes; L corolla opened out to show anthers; M ovary and style. PHOTOS: DIPANKAR BORAH. 
unequal in each pair, $6.5-12 \times 4.5-6.5 \mathrm{~cm}$, ovate or elliptic; apex shortly acuminate; basally rounded and then abruptly narrowed to a shortly cuneate, asymmetric base, shortly decurrent onto the petiole; margin crenate with broad teeth $8-10 \mathrm{~mm}$ wide, ciliate with brownish stiff hairs; both leaf surfaces glabrous (except margins), adaxially dark green, abaxially paler; veins $5-6$ pairs; petioles 2.5 - $5.5 \mathrm{~cm}$ long, diminishing in size upwards, glabrous. Inflorescence formed of axillary pedunculate, bracteate capitula; peduncles $(0.5-) 1.75$ $4 \mathrm{~cm}$ long, ascending, spreading or somewhat pendulous, glabrous; capitula c. $2.5-3 \mathrm{~cm}$ long, formed of reduced racemes of up to 10 flowers, the internodes between the flower pairs up to $4 \mathrm{~mm}$ below, diminishing upwards, up to three flowers open at any one time; outer bracts $2.1 \times 1.2 \mathrm{~cm}$, foliose, broadly oblong-elliptic, rounded to obtuse, the margins repand to undulate, thinly ciliate with scattered white hairs; inner bracts $1.3-1.5 \times 0.5$ $\mathrm{cm}$, ovate with a narrowed obtuse apical part to obclavate, pale green with darker apex, the margin ciliate; bracteoles $8-9 \times 1.5-2 \mathrm{~mm}$, oblong to oblong-pandurate, weakly keeled, obtuse to rounded, the margin thinly ciliate, green; pedicels $1-2$ $\mathrm{mm}$, glabrous; calyx subequally 5-lobed to base, lobes $14 \times 2-2.25 \mathrm{~mm}$ linear-oblong, narrowed to a subacute or obtuse apex, ciliate, white becoming pale green apically and on the margins; corolla $3.3 \mathrm{~cm}$ long, white with dark pink veins, pilose on the exterior, the interior glabrous except for the filament curtain, the tube campanulate, straight, lobes 5 , spreading, broadly ovate, rounded, c. $6 \times 5$ $\mathrm{mm}$; stamens 4, didynamous, filaments thinly pilose below, glabrous above, the shorter pair c. $10 \mathrm{~mm}$ long, the longer pair slightly unequal, $14-15 \mathrm{~mm}$ long, held at corolla mouth, anthers pale yellow, incurved, broadly ellipsoid, $0.75-1.25 \times 0.5-0.75$ $\mathrm{mm}$, those of the longer stamens slightly larger with a shortly excurrent connective; style 2.7 $3 \mathrm{~cm}$ long, glabrous, white, very shortly exserted, stigma curved; ovary ellipsoid, comose, disc orange. Capsule and seeds not seen. Figs 1, 2.

RECOGNITION. The small incurved, broadly ellipsoid anthers indicate this species belongs to the Goldfussia group of Strobilanthes species which is well-represented in the Himalayas. However, the white flowers and creeping habit are unusual and suggest an affinity with S. nutans (Nees) T.Anderson, which is endemic to Nepal and has similar subequal calyx lobes. The new species differs in the glabrous stem and leaves (apart from the ciliate leaf margins), the subcapitate inflorescence and in

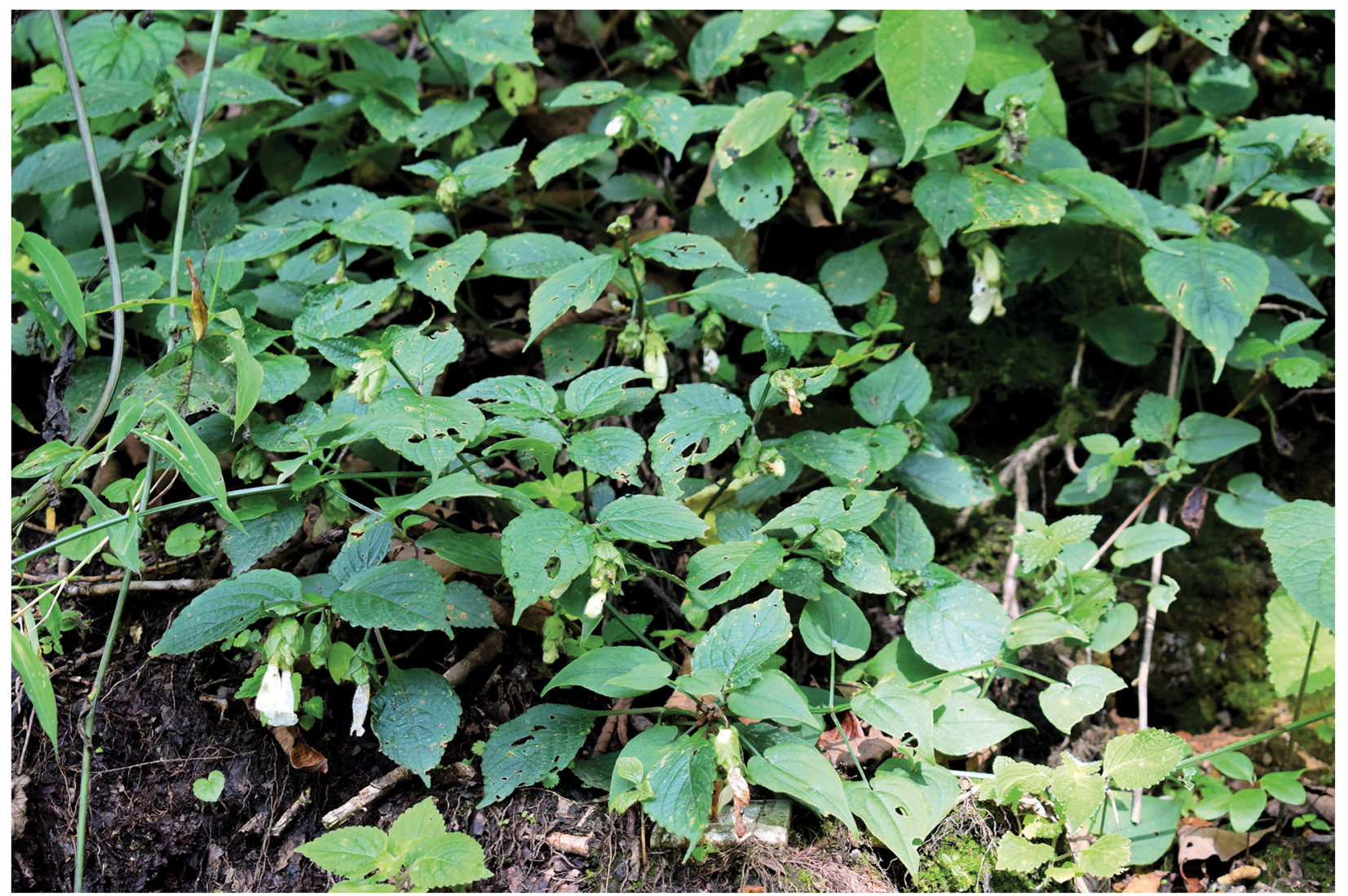

Fig. 2. Growth habit of Strobilanthes twangensis. PHOTO: DIPANKAR BORAH. 


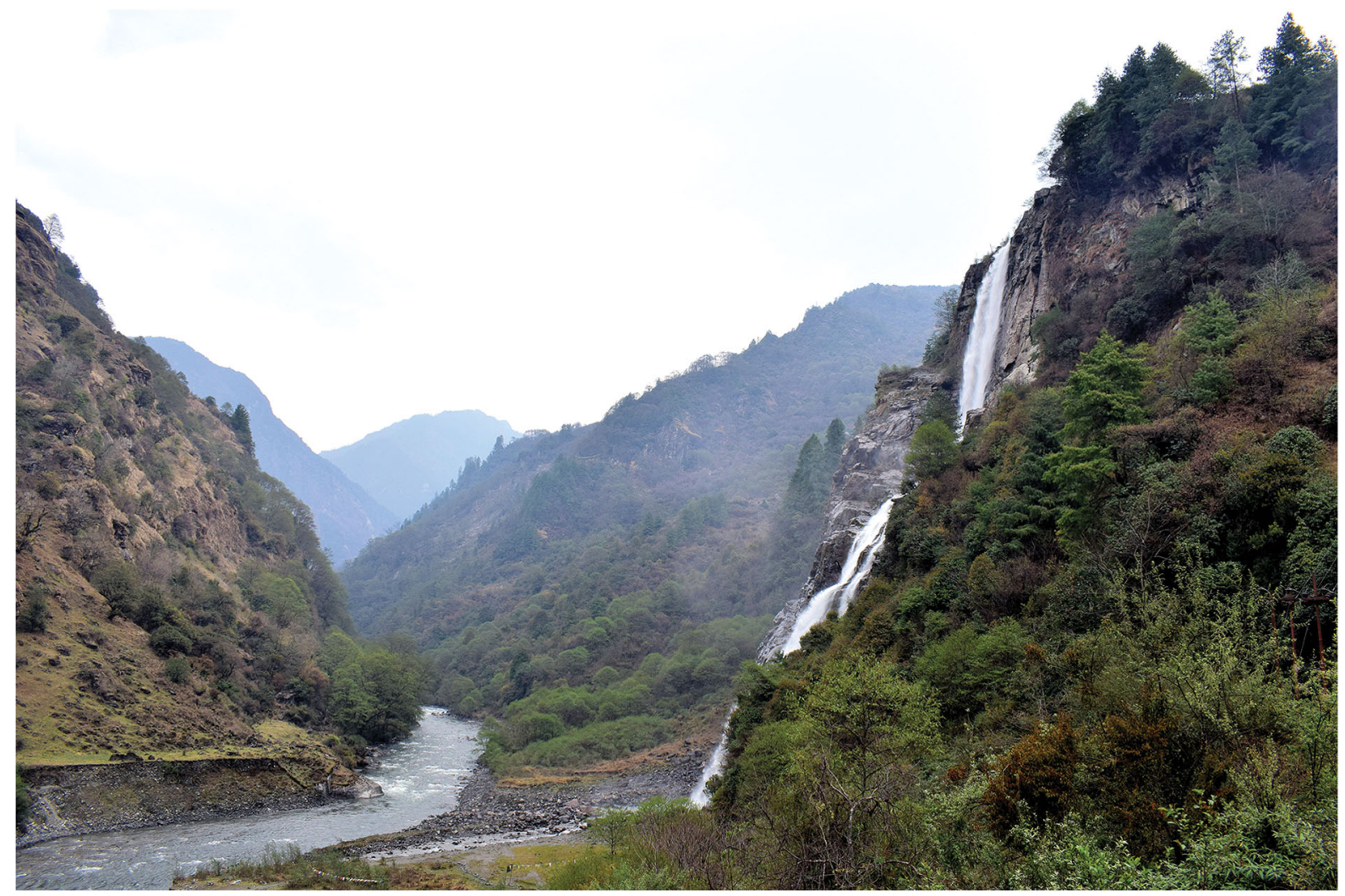

Fig. 3. Natural habitat of Strobilanthes twangensis, a narrow wooded Himalayan valley. PHOTO: DIPANKAR BORAH.

the green, foliose persistent outer bracts with a repand or undulate, ciliate margin. In S. nutans the stem and leaves are uniformly pilose, the inflorescence is formed of drooping, cone-like spikes with glabrous, deciduous, pale green, entire bracts (Wood \& Adhikari 2014). The new species also somewhat resembles $S$. jennyae J.R.I.Wood in habit, flower colour and androecium (Wood 1994). $S$. jennyae grows in not very distant locations in Eastern Bhutan but is distinguished by its conspicuous pilose indumentum with large-celled, brown

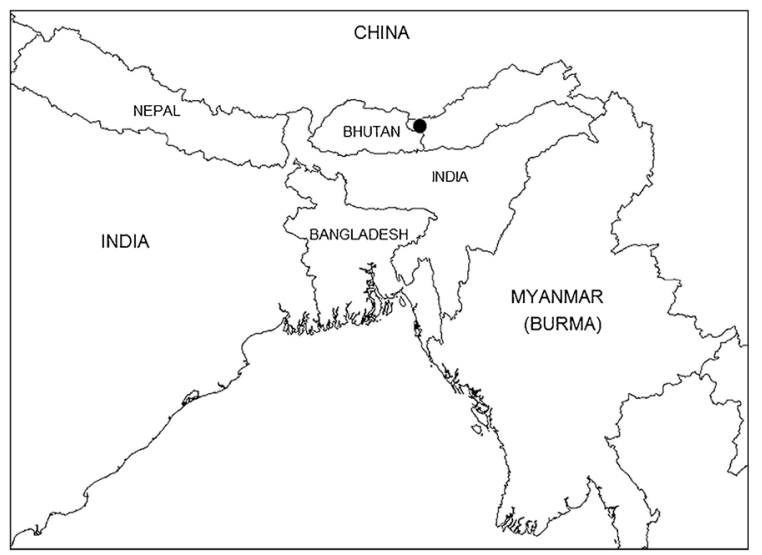

Map 1. Eastern India and surrounding countries showing location of Strobilanthes twangensis. hairs, its lax spicate inflorescence and oblongelliptic bracts.

HABITAT \& DISTRIBUTION. The new species is endemic to the Tawang district in the extreme NW of Arunachal Pradesh (Map 1). Its natural habitat appears to be shaded banks under canopy trees in mixed temperate forest relicts but it also occurs on roadsides. It is restricted to at least seven nearby locations around the township of Jang in Tawang district where it grows between 2440 and $2750 \mathrm{~m}$, around $27^{\circ} 34^{\prime} \mathrm{N}$ and $91^{\circ} 59^{\prime} \mathrm{E}$. The vegetation of this area has been much altered. The steep-sided Himalayan valley sides (Fig. 3) would originally have been covered with trees like Magnolia campbellii Hook.f. \& Thomson and species of Alnus Mill., Rhus L. etc. Today the new Strobilanthes is associated with plants typical of secondary vegetation including Cirsium falconeri Petr., Codonopsis gracilis Hook.f. \& Thomson and species of Euphorbia L., Eleagnus Tourn. ex L., Gaultheria Kalm ex L., Persicaria (L.) Mill., Anaphalis DC., Geranium Tourn. ex L., Cyanotis D.Don etc. The only other species of Strobilanthes with which it is associated is S. oligocephala T.Anderson ex C.B.Clarke although S. lamiifolia (Nees) T.Anderson grows in the vicinity.

SPECIMENS EXAMINED. INDIA. Arunachal Pradesh: Tawang Distr., Jang, 27³4'631"N 91 59'025"E, 2524 m, 1 Sept. 2018, Dipankar Borah, Lod Yama E Puranjoy Mipun 098 (holotype CAL, isotypes ARUN, ASSAM). 
CONSERVATION Status. Data Deficient (DD). No formal assessment of the population or threats to its existence have been made. However, at least 2000 individuals have been noted in the Jang area and the species seems well-adapted to deforestation as it grows frequently on roadsides. Road construction is, consequently, a potential danger which could wipe out most known populations as it is more common on roadsides than in natural forest areas.

ETYMOLOGY. The epithet twangensis is not a misspelling of the district name Tawang but is chosen to reflect the pronunciation "twang" used by the Monpa people who inhabit the district.

NOTE. Strobilanthes twangensis was originally found and photographed in flower in 2017 and was collected and again photographed in flower in 2018. It appears, therefore, to be an annual flowering species like many that grow at higher altitudes such as S. attenuata (Nees) T.Anderson, S. nutans, S. lachenensis C.B.Clarke and, at least in the East Himalayas, S. atrocyanea Nees.

Open Access This article is distributed under the terms of the Creative Commons Attribution 4.0
International License (http://creativecommons.org/ licenses/by/4.0/), which permits unrestricted use, distribution, and reproduction in any medium, provided you give appropriate credit to the original author(s) and the source, provide a link to the Creative Commons license, and indicate if changes were made.

\section{References}

Wood, J. R. I. (1994). Notes relating to the Flora of

Bhutan: Acanthaceae with special reference to Strobilanthes. Edinburgh J. Bot. 51(2): 175 - 273.

(2016). The rediscovery of long-lost Acanthaceae from the Himalayan Region. Oxford Pl. Syst. 22: 16.

\& Adhikari, B. (2014). Strobilanthes nutans. Curtis's Bot. Mag. 31(2): 168 - 179.

\section{Publisher's Note}

Springer Nature remains neutral with regard to jurisdictional claims in published maps and institutional affiliations. 